\title{
Play as a stimulator for the development of children with West syndrome and other epileptic encephalopathies at early ages
}

\author{
Víctor Del Toro Alonso \\ Pilar Gútiez Cuevas \\ Universidad Complutense de Madrid. Spain. \\ vdeltoro@ucm.es \\ pigutiez@ucm.es
}

José Antonio Torres González

Universidad de Jaén. Spain.

jtorres@ujaen.es

Received: 31/10/2019

Accepted: 2/6/2020

Published: 29/1/2021

\begin{abstract}
Games can be an ideal tool to stimulate the development of children aged 0 to 6 years with West syndrome (Del Toro, 2013). This study aims to provide an overview of intervention through play in children with epileptic encephalopathies, starting with knowledge of its development and ending with an intervention model for this population. Research is presented that was conducted with 53 children with epileptic encephalopathies and aimed at generating scientific knowledge about the features of play development among such children and basic aspects to present a suitable educational response in keeping with their needs. This descriptive approach follows a non-experimental expost-facto type methodology and data was captured using the poll technique. A playbased intervention is also presented in the form of a case study comparing the development of children who have worked with this play-based program and those who have not. The results show that pupils with epileptic encephalopathy that have followed a play-based program have better motor, linguistic and cognitive development.
\end{abstract}

Keywords: early childhood; play; development; West syndrome and epileptic encephalopathies

Resum. El joc com a estimulador del desenvolupament d'infants amb sindrome de West $i$ altres encefalopaties epilèptiques en edats primerenques

El joc pot ser una eina ideal per estimular el desenvolupament dels infants amb síndrome de West entre 0 i 6 anys de vida (Del Toro, 2013). Aquest treball aporta una perspectiva global de la intervenció a través del joc en nens amb encefalopaties epilèptiques, partint del coneixement del seu desenvolupament i arribant a un model d'intervenció per a aquesta població. S'exposa una investigació realitzada amb 53 nens amb encefalopaties epilèptiques que té com a objectiu generar coneixement científic sobre les característiques del desenvolupament del joc en aquest tipus d'alumnes, aspectes bàsics per presentar una resposta educativa adequada a les seves necessitats. L'estudi descriptiu segueix una metodologia no experimental del tipus ex post facto i, a través d'un estudi de casos, la recollida 
de dades s'ha realitzat a través d'una tècnica d'enquesta. També s'hi presenta una intervenció basada en el joc i una comparació sobre el desenvolupament dels infants que han treballat amb aquest programa i els que no han seguit un programa lúdic. Els resultats de l'estudi de casos mostren que els alumnes amb encefalopaties epilèptiques que han seguit un programa basat en el joc milloren el seu desenvolupament cognitiu, lingüístic i motor.

Paraules clau: primera infancia; joc; desenvolupament; síndrome de West; encefalopaties epilèptiques

Resumen. El juego como estimulador del desarrollo de niños con sindrome de West y otras encefalopatías epilépticas en edades tempranas

El juego puede ser una herramienta ideal para estimular el desarrollo de los niños con síndrome de West entre 0 y 6 años de vida (Del Toro, 2013). Este trabajo aporta una perspectiva global de la intervención a través del juego en niños con encefalopatías epilépticas, partiendo del conocimiento de su desarrollo y terminando con un modelo de intervención con esta población. Se expone una investigación realizada con 53 niños con encefalopatías epilépticas que tiene como objetivo generar conocimiento científico sobre las características del desarrollo del juego en este tipo de alumnos, aspectos básicos para presentar una respuesta educativa adecuada a sus necesidades. El estudio descriptivo sigue una metodología no experimental del tipo ex post facto y la recogida de datos se ha realizado a través de una técnica de encuesta. También se presenta una intervención basada en el juego, a través de un estudio de casos, y una comparación sobre el desarrollo de los niños que han trabajado con este programa y aquellos que no han seguido un programa lúdico. Los resultados del estudio de casos muestran que los alumnos con encefalopatías epilépticas que han seguido un programa basado en el juego presentan mejoras en su desarrollo cognitivo, lingüístico y motor.

Palabras clave: primera infancia; juego; desarrollo; síndrome de West; encefalopatías epilépticas

\section{Summary}

$\begin{aligned} \text { 1. Introduction } & \text { 4. Discussion } \\ \text { 2. Methods } & \text { 5. Conclusions } \\ \text { 3. Results } & \text { Bibliographical references }\end{aligned}$

\section{Introduction}

West syndrome is a type of epileptic encephalopathy that appears at early ages and affects the general development of the child. It mainly involves the appearance of learning difficulties, as well as cognitive, social interaction and communicative difficulties, or behavioural problems (Chapple \& Kinsella, 2019; Besag \& Vasey, 2019; Van Campen et al., 2015).

Of the different paediatric epileptic syndromes, which include the West syndrome, the present study deals with Lennox syndrome, Gastaut, Dravet syndrome, Ohtahara syndrome and Aicardi syndrome. 
West syndrome represents $45.5 \%$ of epilepsies during the first year of life (Durá-Travé, Yoldi-Petri \& Gallinas-Victoriano, 2008) and it is characterized by the following symptomatic triad: (1), spasms, (2) EEG with hypsarrhythmia and (3) detection of the neurological maturation process at the beginning of critical manifestations, implicating psychomotor delay (Calderón et al., 2018; Arce et al., 2011).

Child spasms are crucial for the diagnosis of the syndrome. These crises are characterized by short flexion, extension and mixed axial contractions, the latter being the most common (Pavone, Striano, Falsaperla, Pavone \& Ruggieri, 2014).

Lennox-Gastaut syndrome is an infant epileptic encephalopathy characterized by the presence of refractory crisis, cognitive impairment and abnormal EEG (Kerr, Kluger \& Philip, 2011). This epileptic pattern usually shows different types of crisis, such as axial tonic, atonic, mioclonic and convulsive epileptic state (Campos-Castelló, 2005).

Dravet syndrome is of genetic origin, more specifically in the cases that present mutation in the SCN1A gene (Dravet, 2011). In this epileptic pattern, development is normal until the first convulsive crisis and happens in the first year of life.

Table 1. Characteristics of the development of children with Epileptic Encephalopathies

\begin{tabular}{|c|c|c|c|c|}
\hline & \multicolumn{4}{|c|}{$\begin{array}{l}\text { Epileptic Encephalopathies } \\
\text { According to age of appearance. The younger the age of appearance, the grea- } \\
\text { ter the impact on cognitive, motor and communicative-linguistic development. }\end{array}$} \\
\hline & $\begin{array}{l}\text { West syndrome } \\
\text { (between } 3 \\
\text { months and } 2 \\
\text { years old.) }\end{array}$ & $\begin{array}{l}\text { Lennox- Gastaut } \\
\text { syndrome } \\
\text { (between } 2 \text { and } 6 \\
\text { years old.) }\end{array}$ & $\begin{array}{l}\text { Dravet syndrome } \\
\text { (between } 4 \text { and } 12 \\
\text { months old.) }\end{array}$ & $\begin{array}{l}\text { Ohtahara } \\
\text { syndrome (during } \\
\text { the first } 3 \text { months } \\
\text { of life.) }\end{array}$ \\
\hline $\begin{array}{l}\text { Cognitive } \\
\text { development }\end{array}$ & \multicolumn{4}{|c|}{$\begin{array}{l}\text { Intellectual disability (Spenner et al., 2019; Campos-Castelló, 2005). } \\
\text { Sensory processing disorder (Van Campen et al., 2015). } \\
\text { Difficulties in modulation, awareness and attention processes (Van Rijckevorsel, } \\
\text { 2006; Aldenkamp, Alpherts, Dekker \& Overweg 1990; Berg et al., 2007). } \\
\text { Disturbances in memory, attention and slow response (Orock, Logan \& Deak, } \\
\text { 2018; Van Rijckevorsel, 2006; Aldenkamp et al., 1990; Berg et al., 2007). } \\
\text { Disorders in nomination, planning and organization (Van Rijckevorsel, 2006). } \\
\text { Low IQ (Berg et al., 2007). }\end{array}$} \\
\hline $\begin{array}{l}\text { Motor } \\
\text { development }\end{array}$ & $\begin{array}{l}\text { Generalized } \\
\text { delayed motor } \\
\text { development } \\
\text { Stereotypes. }\end{array}$ & $\begin{array}{l}\text { Generalized } \\
\text { delayed motor } \\
\text { development } \\
\text { Stereotypes } \\
\text { Hyperactivity. }\end{array}$ & $\begin{array}{l}\text { Generalized dela- } \\
\text { yed motor develo- } \\
\text { pment } \\
\text { Stereotypes } \\
\text { Ataxia. }\end{array}$ & $\begin{array}{l}\text { Generalized dela- } \\
\text { yed motor develo- } \\
\text { pment } \\
\text { Stereotypes. }\end{array}$ \\
\hline $\begin{array}{l}\text { Linguistic- } \\
\text { Communicative } \\
\text { Development }\end{array}$ & \multicolumn{4}{|c|}{$\begin{array}{l}\text { Expressive and comprehensive language difficulties (Van Rijckevorsel, 2006; } \\
\text { Wheless, Simos \& Butler, 2002). }\end{array}$} \\
\hline $\begin{array}{l}\text { Social-Emotio- } \\
\text { nal Develop- } \\
\text { ment }\end{array}$ & \multicolumn{4}{|c|}{$\begin{array}{l}\text { Impairments in social cognition (Besag \& Vasey, 2019). } \\
\text { Anxiety and loss of control (Williams, 2003). } \\
\text { Usually attached to the cognitive component. }\end{array}$} \\
\hline
\end{tabular}

Source: Own elaboration. 
Neonatal epileptic encephalopathies include Aicardi syndrome and Ohtahara syndrome, which share similar characteristics, the most important of which are severe psychomotor and cognitive deterioration.

Children with epileptic encephalopathies usually present serious difficulties with motor, cognitive, communicative and social development. These can be highly variable depending on the development of the nervous system, the cause of the encephalopathy, the onset of seizures and the treatment used.

In a study on neurological development in children with epileptic encephalopathies (De Tiége et al., 2007), disorders were detected in cortical activity in the prefrontal, parietal, posterior cingulate and cerebellum areas that cause both cognitive and behavioural disorders, whereby difficulties arise in the thalamo-cortical and hippocampal-cortical networks related to memory, psychomotor and executory processes.

\subsection{Game challenges in pupils with epileptic encephalopathies}

Games are an ideal tool to support learning among infants because they represent an activity that they understand perfectly and can therefore help to develop their full range of habits, skills and capabilities (Richards, 2017; Del Toro, 2016; Del Toro, 2013; Garaigordobil, 2007; Garvey, 1990).

We consider functional games to be playful activities that exercise the body using objects and people, and which can be manipulated and used to explore one's environment.

The benefits are numerous, beginning with the development of the senses, an understanding of one's immediate environment, socialization with adults and psycho-motor abilities (Richards, 2017; Garaigordobil, 2007).

A symbolic game consists of the capacity to simulate situations, objects or people through play. This semiotic or symbolic capacity in relation to play is what is called "do as if", whereby the ludic symbol represents the distance between what is being symbolised and the real object. The child uses patterns that they have learned previously from situations in a sensorimotor functional game to construct a scaffold (Bruner, 1961).

The benefits of symbolic games for child development range from an understanding of his/her environment and social reality to the development of language, imagination and creativity (Garaigordobil, 2007).

Children with disabilities present a series of limitations in their development but they are able to play. Their education must include games that will allow them to learn.

Children with epileptic encephalopathies have restricted habits and tend to prefer sensor toys, for they have difficulties with games that involve imitation, functions, symbolism and rules (Del Toro, 2013).

Considering these pupils' characteristics, games are highly recommendable and positive for their development (Del Toro, 2013). Particularly recommendable are a) games that develop memory, b) games that increase selective and sustained attention, c) games that develop planning and execution of respons- 
es, d) games that develop manipulation and maximize wandering, e) games that encourage group attention, f) games that encourage group action, g) games that develop the use of symbols, $h$ ) games that stimulate communicative intention, i) games that develop functional communication, j) games that increase love for movement, $\mathrm{k}$ ) appealing games than increase motivation and l) comprehensible and predictable games that make the usage of rules easy.

The main challenges for using games to stimulate these children are (Del Toro, 2013): 1) to develop and enhance proprioceptive, vestibular, tactile, auditory and visual sensory integration as a fundamental basis of learning, 2) to include processes that lead to the development of imitation of simple and complex actions and sequences of symbolic play that serve as an anchor to develop the function and access to the symbol, which can be achieved using a Reciprocal Imitation Training program, 3) to embrace free-play experiences as the best way to create potential learning environments, 4) to incorporate play spaces that enhance the handling of objects and symbolic development and 5) to create understandable and highly structured routines that facilitate an understanding of playful action through visual supports.

\section{Methods}

This article is both descriptive and also presents a case study designed to show the developmental needs and benefits of children with epileptic encephalopathies. This is a poorly studied population on which we need to improve our knowledge in both psychological and pedagogical terms.

\subsection{Descriptive study}

We begin by describing a non-experimental, ex-post-facto research study into the development and play habits of a non-probabilistic and intentional sample of 53 children aged 0 to 6 years with epileptic encephalopathies.

The sample was obtained from the West Syndrome Foundation and the Early Childhood Intervention Team at Navalcarnero (Madrid) for the school years from 2015 to 2018 , having previously received authorisation from the families and schools.

A questionnaire was used to obtain information to produce a descriptive study of the aforesaid sample, and the children were directly observed at play by two researchers.

The games that were used in this intervention were didactically designed to be used in a regulated, structured, systematic and continuous manner, and were as follows:

1. Sensorimotor pleasure games: these are activities aimed at developing sensory integration in a free and playful manner (Del Toro, 2013), such as sensory boxes, sliding activities, swinging, balancing, being wrapped in different textures, being chased and climbing and jumping. These are all 
complemented by activities that gradually enhance proprioception, such as massages with different appealing materials, visual tracking and sweeping of one's own body, use of vibrating objects, association between actions and body parts, searching for sound sources and auditory discrimination. Play actions are also included to develop the vestibular system, such as rotating and exercises with large balls, rollers and cylinders.

2. Reciprocal imitation games: These are games in which the adult imitates actions at moments of play, to increase the child's attention, and encourages the child to also imitate movements and propose new ones. This activity includes actions such as exploratory play, cause and effect toys, functional play, self-directed pretend play, symbolic play and complex pretend play (Del Toro, 2016; Ingersoll \& Meyer, 2011; Ingersoll, 2010).

3. Treasure basket: this activity involves a basket containing about 50 materials that relate to the child's experience, and which are easy to handle and help to develop the senses, so the child develops his/her ability to deal with the functionality of objects (Del Toro, 2013).

4. Heuristic play: the child is presented with different types of materials to play with that will help them to understand their possibilities (Del Toro, 2013; Garaigordobil, 2007). Manipulation, discovery and learning are developed by combining object functions. Possible objects include those that can be filled and emptied, like buckets and boxes, and various items like balls, rings, bags, tubes, blocks for building and destroying, toy cars, dolls, and others.

5. Symbolic play activities: This consists of presenting children toys that offer opportunities to symbolize (Del Toro, 2013; Garaigordobil, 2007, Garvey, 1990). For example, playing house, or pretending to be a doctor, babysitter or cook.

\subsection{Case study}

The primary objective of the case study is to deepen our understanding of play methodology and its impact on child development. Using a descriptive study and a case study will provide us with more information and greater comparative scope. The children included in this study previously participated in the descriptive study.

This study evaluates a pre-test and a post-test situation using two groups, the first of which worked with a play methodology and the second with a traditional methodology.

\subsection{Participant characteristics and criteria for inclusion}

The case study began with a data collection phase. In order to include 10 pupils with different types of epileptic encephalopathy, such as West syndrome, Lennox-Gastaut syndrome, Dravet or Ohtahara, we made a selection based on the following criteria: a) aged from 24 to 36 months, b) must pre- 
sent the same diagnosis, in this case West syndrome c) epileptic seizures must have first appeared at similar times and d) a similar quotient of development (QD).

In this case the exclusion criteria were as follows: a) being of a different age from other children in the study, b) being diagnosed with a different epileptic encephalopathy to West syndrome, c) first seizures happening more than 2 months before or after they did for the others, d) a QD on the Bayley III scale with a difference of more or less than 10 points.

Following a review, we selected 4 cases that meet all the requirements. Two of these attend a school that uses play as a learning tool. The other two children have been attending a traditional school where free play is not used and activities are instead commonly based on an 'educational sheet' system. Therefore, cases 1 and 2 receive the play-based intervention and only an initial and a final evaluation are performed for cases 3 and 4 .

Case 1: 29 month old boy with West syndrome. The first seizure happened at 3 months of age, after which different antiepileptic drugs were used. Before the study, the child had a quotient of development in the cognitive area of the Bayley Scales of Infant and Toddler Development - Third Edition (Bayley III) of 60, showing attention difficulties, slow response time and motor delay.

Case 2: 30 month old boy who also has West Syndrome. The first seizure happened at 3 months of age, and antiepileptic drugs have been used since then. His Development Quotient in the Bayley III cognitive area is 55, in addition to obvious difficulties observed in attention, slow time response and motor delay.

Case 3: 29 months and 10 days old boy who also has West syndrome. The first seizure happened at 4 months of age and he has been using antiepileptic drugs since then. His Development Quotient in the Bayley III cognitive area is 65 .

Case 4: 26 months and 25 days old boy diagnosed with West syndrome. The first seizure happened at 3 months of age and he has been on antiepileptic drugs since then. His Development Quotient in the Bayley III cognitive area is 65 .

The collection of information used medical reports issued by the neurological and psychology assessment reports made by the Early Intervention Team.

\subsection{Objectives of the intervention}

The play-based intervention was scheduled for one academic year, the objectives being:

1. To promote the children's development using play as a methodological tool.

2. To develop an intervention model adjusted to the needs of children with epileptic encephalopathies at early ages. 
3. To observe whether there is any variance in the different areas of development between children who have been stimulated using a play-based methodology and those who have not.

\subsection{Intervention characteristics}

The intervention uses a play-based model involving such principles as free movement (Pikler, 1971) and constructivist learning (Bruner, 1961).

The chosen space is the kindergarten classroom, which the sampled children share with others that do not have special educational needs.

Five play routines were proposed for the children to do every day in class: 1) sensorimotor pleasure games, 2) reciprocal imitation games, 3) treasure basket, 4) heuristic play, and 5) symbolic play activities.

The sequence of events is as follows:

$1^{\text {st }}$ Activity: Reciprocal imitation games: The teacher proposes actions to be imitated in the recreational activity for 15 minutes. This activity includes: games that imitate patterns present in their repertoire, simple motor pattern imitation games, complex motor pattern imitation games, games imitating symbolic play sequences and games imitating social behaviour. This activity is carried out daily.

$2^{\text {nd }}$ Activity: Sensorimotor pleasure games: These games are played taking into account three types of activities. On the one hand, a sensory box is introduced to the class once a week. These contain different materials and textures such as flour, sugar, bread crumbs, foam, yogurt, liquid chocolate, soap bubbles, cream, different types of sand or different fabrics. Secondly, there is an experienced psychomotricity session every week that includes balance and imbalance of the body itself, dragging, crawling, sliding, rolling and jumping. These sessions will also include filling and emptying, building and destroying and chasing experiences. They are held in a group with adult guidance and last for 45 minutes. Finally, individual sessions work with massages, large balls, rollers and objects that develop proprioception and the vestibular area, and which are done at a weekly 45-minute session.

$3^{\text {rd }}$ Activity: Treasure basket: the basket with selected materials is presented to the child for 30 minutes. On Mondays and Wednesdays, they play in small groups with the treasure basket and a different selection of materials.

$4^{\text {th }}$ Activity: Heuristic Play: the selected materials are presented for the child to manipulate, explore and combine object functions for 30 minutes. On Tuesdays and Thursdays: heuristic play in a large group with a different selection of materials.

$5^{\text {th }}$ Activity: symbolic play activities: Choice of one of the four corners of the classroom (house corner, functional play corner, artistic corner and building corner) mediated by the child to create opportunities for pre-symbolic and symbolic play. On Friday: symbolic play in groups, and alternating the four corners each month. 


\subsection{Data collection instruments}

The following tools and techniques were used to collect information for this case study: a) direct, participant and non-participant observation, b) Bayley Scales of Infant and Toddler Development - Third Edition (Bayley III) and c) Game session diary.

Type of observation: participant observation was used in which the researcher is a member of a group that watches the intervention and nonparticipant observation was also used where the observer remains completely outside of the action (Cohen, Manion \& Morrison, 2007). Three people at each school, two researchers and the class teacher performed the observation, after which they agreed on the observed results, only those confirmed by three observers being valid. All these observations are noted in the game session diary and the questionnaire.

The Bayley III test was used to incorporate data on the children's age and Quotient of Development (QD).

We decided to use the instrument, in both cases, at the beginning of the school year and at the end of it, to see how the two students had evolved throughout the year (10 months), using a pre-test and post-test structure.

The following table shows the data collected after administering the Bayley III test in a pre-test and post-test situation.

Table 2. Bayley III test data

\begin{tabular}{|c|c|c|c|c|c|c|c|c|c|}
\hline & & \multicolumn{2}{|c|}{ Case 1} & \multicolumn{2}{|c|}{ Case 2} & \multicolumn{2}{|c|}{ Case 3} & \multicolumn{2}{|c|}{ Case 4} \\
\hline & & Pre-test & $\begin{array}{c}\text { Post- } \\
\text { test }\end{array}$ & Pre-test & $\begin{array}{c}\text { Post- } \\
\text { test }\end{array}$ & $\begin{array}{l}\text { Pre- } \\
\text { test }\end{array}$ & $\begin{array}{c}\text { Post- } \\
\text { test }\end{array}$ & $\begin{array}{l}\text { Pre- } \\
\text { test }\end{array}$ & $\begin{array}{r}\text { Post- } \\
\text { test }\end{array}$ \\
\hline Intervention & & Game & Game & Game & Game & No & No & No & No \\
\hline Age (month) & & 29 & 39 & 26 & 36 & 29 & 39 & 26 & 36 \\
\hline \multirow[t]{2}{*}{ Cognitive } & $\begin{array}{l}\text { DS } \\
\text { SC }\end{array}$ & $\begin{array}{r}43 \\
2\end{array}$ & $\begin{array}{r}50 \\
3\end{array}$ & $\begin{array}{r}40 \\
1\end{array}$ & $\begin{array}{r}48 \\
2\end{array}$ & $\begin{array}{r}50 \\
3\end{array}$ & $\begin{array}{r}51 \\
3\end{array}$ & $\begin{array}{r}45 \\
2\end{array}$ & $\begin{array}{r}46 \\
2\end{array}$ \\
\hline & DQ & 60 & 65 & 55 & 60 & 65 & 65 & 60 & 60 \\
\hline \multirow[t]{3}{*}{ Language } & $\begin{array}{l}\text { Receptive } \\
\text { DS } \\
\text { SC }\end{array}$ & $\begin{array}{r}13 \\
3\end{array}$ & $\begin{array}{r}18 \\
4\end{array}$ & $\begin{array}{r}18 \\
4\end{array}$ & $\begin{array}{r}18 \\
4\end{array}$ & $\begin{array}{r}19 \\
4\end{array}$ & $\begin{array}{r}19 \\
4\end{array}$ & $\begin{array}{r}16 \\
3\end{array}$ & $\begin{array}{r}16 \\
3\end{array}$ \\
\hline & $\begin{array}{c}\text { Expressive } \\
\text { DS } \\
\text { SC }\end{array}$ & $\begin{array}{r}14 \\
3\end{array}$ & $\begin{array}{r}18 \\
3\end{array}$ & $\begin{array}{r}13 \\
2\end{array}$ & $\begin{array}{r}18 \\
3\end{array}$ & $\begin{array}{r}22 \\
4\end{array}$ & $\begin{array}{r}25 \\
4\end{array}$ & $\begin{array}{r}11 \\
1\end{array}$ & $\begin{array}{r}12 \\
1\end{array}$ \\
\hline & DQ & 59 & 62 & 53 & 59 & 65 & 65 & 53 & 53 \\
\hline \multirow[t]{3}{*}{ Motor } & $\begin{array}{l}\text { Fine } \\
\text { DS } \\
\text { SC }\end{array}$ & $\begin{array}{r}30 \\
3\end{array}$ & $\begin{array}{r}33 \\
3\end{array}$ & $\begin{array}{r}30 \\
3\end{array}$ & $\begin{array}{r}30 \\
2\end{array}$ & $\begin{array}{r}35 \\
4\end{array}$ & $\begin{array}{r}35 \\
4\end{array}$ & $\begin{array}{r}29 \\
2\end{array}$ & $\begin{array}{r}30 \\
2\end{array}$ \\
\hline & $\begin{array}{c}\text { Gross } \\
\text { DS } \\
\text { SC }\end{array}$ & $\begin{array}{r}47 \\
4\end{array}$ & $\begin{array}{r}55 \\
5\end{array}$ & $\begin{array}{r}47 \\
4\end{array}$ & $\begin{array}{r}49 \\
3\end{array}$ & $\begin{array}{r}54 \\
4\end{array}$ & $\begin{array}{r}54 \\
4\end{array}$ & $\begin{array}{r}46 \\
2\end{array}$ & $\begin{array}{r}47 \\
2\end{array}$ \\
\hline & DQ & 61 & 64 & 52 & 55 & 64 & 64 & 52 & 52 \\
\hline
\end{tabular}

$\mathrm{DS}=$ Direct Score; $\mathrm{SC}=$ Scalar Score; $\mathrm{DQ}=$ Development Quotient Source: Own elaboration. 
Figure 1. Bayley III Data Test
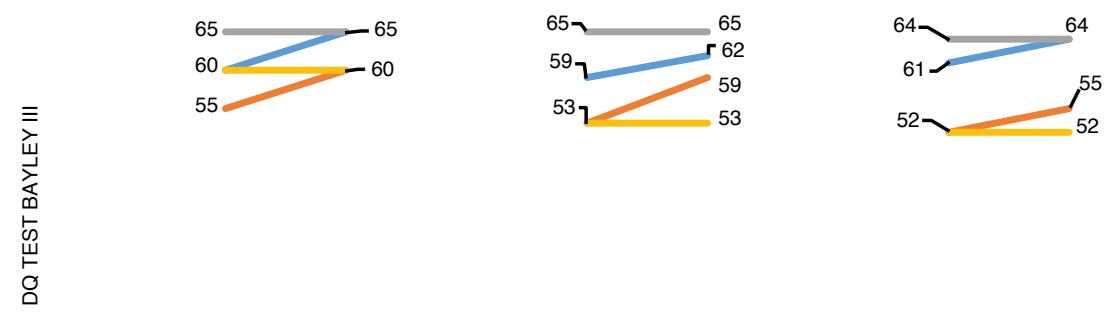

Cognitive

Language

Motor

PRE-TEST / POST-TEST

Game Case 1

Game Case 2

No Game Case 3

No Game Case 4

Source: Own elaboration.

The play session diary was used to collect all the data from observations, with the teacher's help, to view the children's evolution.

\section{Results}

\subsection{Descriptive study results}

The following results were obtained from the 53 students with epileptic encephalopathies (aged 0 to 6 years old): $60.86 \%$ of the sample has West syndrome, versus $8.7 \%$ with Lennox-Gastaut syndrome and $30.43 \%$ with other epileptic encephalopathies.

Figure 2. Distribution of epileptic encephalopathies in the study sample

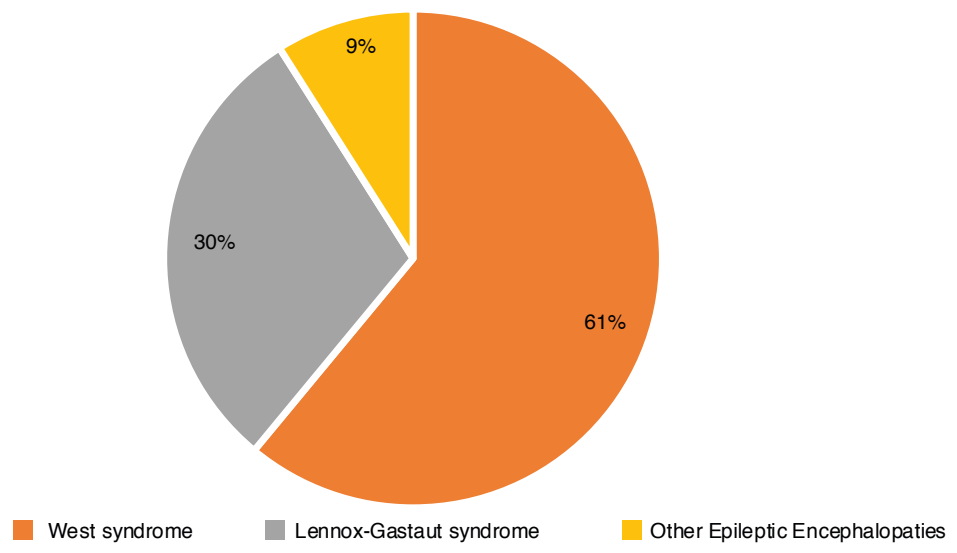

Source: Own elaboration. 
$60.86 \%$ also have a motor disability, $13.04 \%$ auditory disability, $30.43 \%$ visual disability and 30.43\% ASD (Autism Spectrum Disorder).

Figure 3. Disabilities associated with epileptic encephalopathy among children in the sample

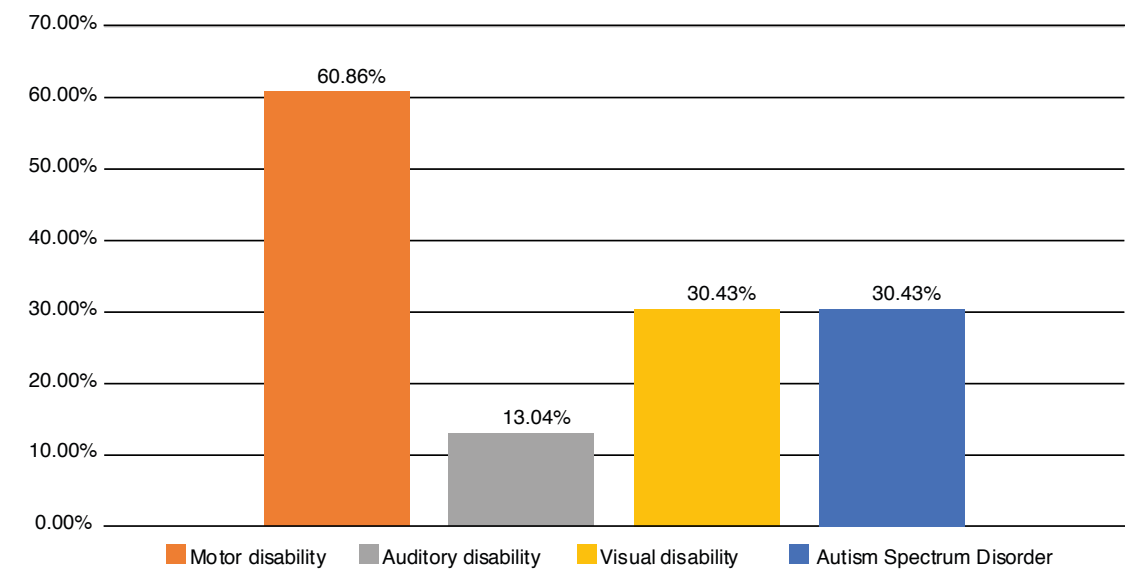

Source: Own elaboration.

$95.65 \%$ of the sample had received early childhood attention, $69.56 \%$ of whom before the first year and $13.04 \%$ between the first and the second year of their lives.

Figure 4. Participation in early attention programmes by children with epileptic encephalopathies

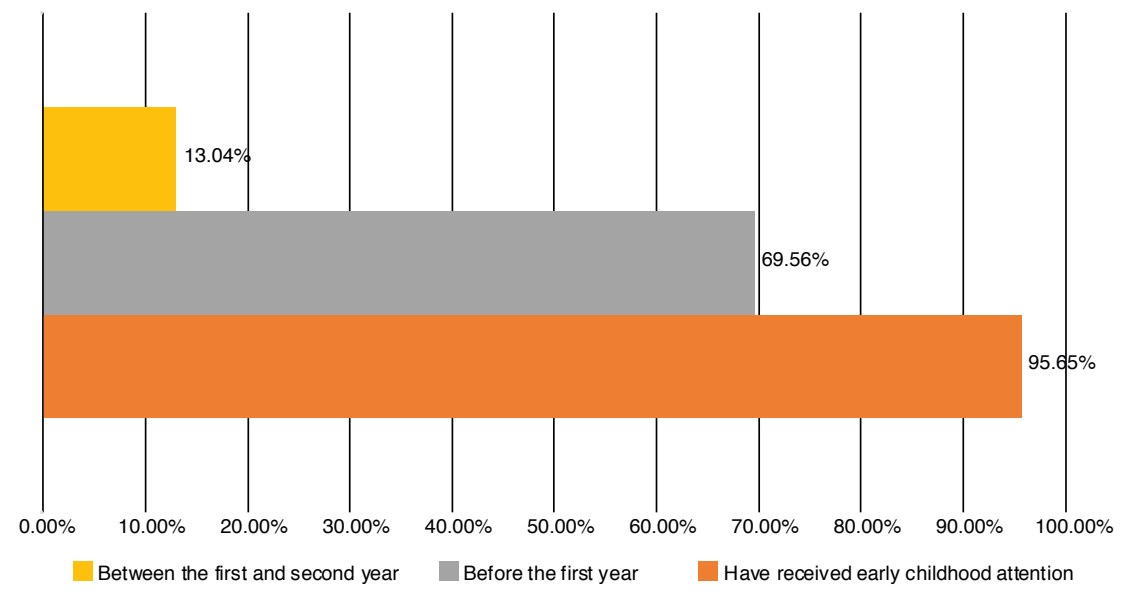

Source: Own elaboration. 
In relation to the development of play, the following results were obtained: a) imitation play: $34.69 \%$ of the sample have trouble imitating actions that they already know, 52.18\% imitating simple motor actions, $91.31 \%$ imitating complex motor actions, $82.61 \%$ imitating symbolic sequences and $65.31 \%$ imitating social actions; b) manipulative play: $21.71 \%$ of the sample show difficulties manipulating and exploring objects and $30.44 \%$ in interacting physically with adults during play; c) functional play: $60.87 \%$ of the sample show many limitations for finding or showing the

Figure 5. Imitation play development in children in the sample

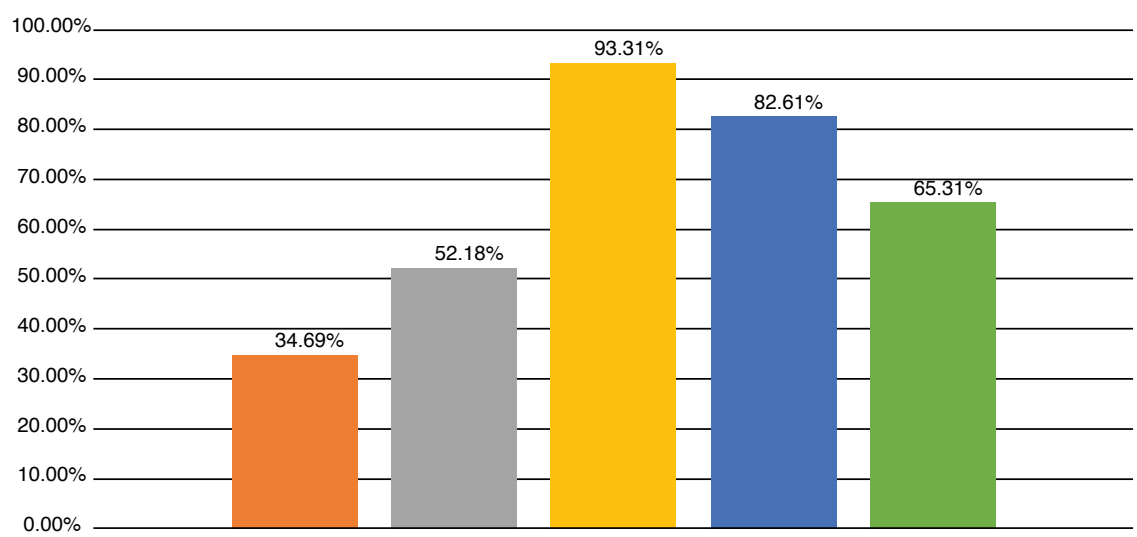

Have trouble imitating actions that they already know

- Have trouble imitating symbolic sequences

Have trouble imitating simple motor actions

Have trouble imitating social actions

Have trouble imitating complex motor actions

Source: Own elaboration.

Figure 6. Development of manipulative, functional and symbolic play in children in the sample

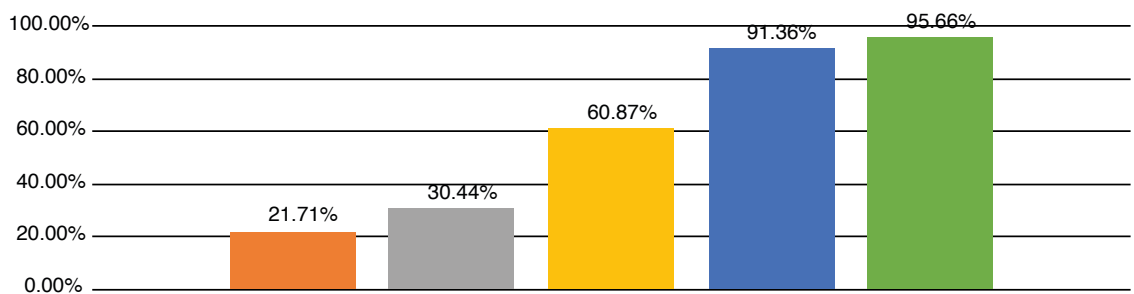

Shows inability manipulating and exploring objects during manipulative play

Shows inability in interacting physically with adults during manipulative play

Functional play of the sample shows lots of limitation in finding or showing

the function of the known and unknown objects

During symbolic play they are not capable of playing "do as if"

During symbolic play they don't make simulating actions

Source: Own elaboration. 
function of known and unknown objects; d) symbolic play: $91.39 \%$ of the sample are not capable of playing "as if" and $95.66 \%$ do not perform simulated actions while playing.

The descriptive study presented aims to approach these children's play needs and the case study seeks to propose a tool for intervention in the classroom.

\subsection{Case study results}

The two children with West syndrome who were on the play programme improved their scores for the Bayley III test. This improvement is observed in the cognitive area (Case 1: pre-test -60-post-test-65; Case 2: pre-test 55post-test 60), communicative-linguistic area (Case 1: pre-test s 59- post-test62; Case 2: post-test 53- post-test 59), and the motor area (Case 1: pre-test .61- post-test 64; Case 2: post-test 52-post-test 55 ). In contrast, no variation in scores was observed in children who were part of the traditional intervention, as can be seen in the cognitive (Case 3: pre-test -65- post-test-65; Case 4: pre-test 60- post-test 60), communicative-linguistic (Case 3: pre-test .65post-test 65; Case 4: pre-test 53- post-test 53) and motor (Case 3: pre-test .64- post-test 64; Case 4: pre-test 52-post-test 52) areas.

Regarding the session diary, it can be highlighted that the students that followed the play methodology had more interactions with objects and participated more in functional games. They also make greater use of motor patterns such as postural changes and motivation for displacement and experimentation.

\section{Discussion}

Play can be considered a children's activity that promotes all of their developmental aspects (Richards, 2017; Del Toro, 2013; Garaigordobil, 2007).

The three key aims of this paper were to describe what disorders commonly occur in children with special educational needs, their participation in early intervention programs and how their play develops.

In our sample, we observed that $60.86 \%$ have West syndrome, $8.7 \%$ have Lennox-Gastaut syndrome and the other $30.43 \%$ have Epileptic encephalopathies such as Dravet and Ohtahara syndrome. Of these, $60.86 \%$ present physical disabilities, $13.04 \%$ hearing disabilities, $30.43 \%$ visual disabilities and $30.43 \%$ Autism Spectrum Disorder.

We found that $95.65 \%$ of the sample had received early intervention, of which $69.56 \%$ received it within the first year of life and $13.04 \%$ between the first and the second year.

This sample reveals that due to their serious disorders, children with epileptic encephalopathies find it very difficult to develop certain aspects of highly complex play, which would seem to be related to access to and use of the symbol during play. The data shows that the greater the developmental 
requirements of a game, the harder it is for these pupils, as is particularly apparent in the cases of imitation and symbolic play.

In the imitation game, $34.69 \%$ have difficulty imitating actions that are in their repertory, $52.18 \%$ imitating simple motor actions, $91.81 \%$ imitating complex motor actions, $82.61 \%$ imitating symbolic play sequences and $65.31 \%$ imitating social actions such as saying hello or goodbye.

In terms of evolution towards symbolic play, $21.71 \%$ have difficulty manipulating and $30.44 \%$ following physical interactive games, $60.87 \%$ searching for or showing the function of toys or objects, $91.39 \%$ playing "as if" games and $95.66 \%$ in the most complex simulation game.

The case study reveals that play is a very useful tool for developing skills in young children with epileptic encephalopathies, for an improvement is observed in this regard in both cases.

The data obtained from these studies shows that play enhances the cognitive, motor and linguistic-communicative development of children with special educational needs, in line with previous studies (Del Toro, 2013, Garaigordobil, 2007). Similarly, children who participated in the play program performed better at the sensorimotor and imitation games, as well as the functional and symbol games.

Comparing the two cases that received the play program (cases 1 and 2) and the other two cases of children that attended traditional school (cases 3 and 4), we observed that after 10 months of the former, children had a better DQ in the Bayley III test in the three areas of development, specifically an increase by 5 points in the cognitive area and an increase by 3 points in the language and motor areas. In turn, no change in post-test DQ was observed after the same period of time in children that received traditional teaching.

The presented play program involves an active methodology that begins at the child's level of development and focuses on sensorial, cognitive, fine and gross motor, social, receptive and expressive-linguistic development. Therefore, it is an indispensable tool for early stimulation of children with special educational needs. This includes children with West syndrome, who have serious difficulties with sensory integration, the development of imitation as a learning strategy and in the acquisition of functional and symbolic play.

The data and observations from the case study lead us to conclude that play therefore helps to reduce this developmental delay, providing children with strategies for accessing environmental requirements, such as knowledge of objects and the symbolic function. It provides experiences that enhance tactile, proprioceptive, vestibular, visual and auditory development, and also favours the acknowledgement of the object, the construction of one's own body, the imitation of other people's models and access to symbolic development (Del Toro, 2013; Garaigordobil, 2007; Garvey, 1990; Bruner, 1961). 


\section{Conclusions}

It is essential to understand the extent to which children suffering from epileptic encephalopathies develop play skills, and to propose a model for playbased intervention in order to offer this population adequate attention from an early age. Play is a tool that offers numerous possibilities for stimulating development (Richards, 2017; Del Toro, 2013; Garaigordobil, 2007).

Regarded the aforesaid descriptive study, we could highlight that: a) more students in the sample suffer from epileptic encephalopathies with West syndrome, and intellectual and motor disability; b) more students in the sample with epileptic encephalopathies have received or are receiving some kind of early childhood care, most of whom started such therapy in their first year of life; c) children in the sample with epileptic encephalopathies have a limited ability to develop imitative, functional and symbolic play.

From the case study, we can conclude that a play-based intervention for children with epileptic encephalopathy helps to improve their development by providing strategies to improve manipulative, motor, cognitive, communicative and social aspects, the aim being for these children to enjoy a better quality of life (Del Toro, 2013).

Play, in these cases, stimulates development, an increase in DQ being observed in all the described areas after a 10 -month intervention 5 points in the cognitive area, 3 points in the language area and 3 points in the motor area) and differences also being observed between children who participated in the play program and those schooled at centres that do not use play as a learning tool.

The limitations of this study include the sample used. It would be useful to expand it and conduct a comparative study among different groups, thus delimiting the impact of play methodologies on the development of children with special educational needs.

\section{Bibliographical references}

Aldenkamp, A.P.; Alpherts, W.C.; Dekker, M.J. \& Overweg (1990). Neuropsychological aspects of learning disabilities in epilepsy. Epilepsia, 31(4), 9-20.

Arce, E.; Rufo, M.; Muñoz, B.; Blanco, B.; Madruga, M.; Ruiz, M. et al (2011). Síndrome de West: etiología, opciones terapéuticas, evolución clínica y factores pronósticos. Rev Neurol, 52, 81-89.

Bayley, N. (2006). Bayley Scales of Infant and Toddler Development- Third Edition. San Antonio, TX: Harcourt Assessment.

Berg, A.T.; Langfitt, J.T.; Testa, F.M.; Levy, S.R.; Di Mario, F.; Westerveld, M. \& Kulas, J. (2007). Global cognitive function in children with epilepsy: A community- based study, Epilepsia, 49(4), 608-614. <https://doi.org/10.1111/j.1528-1167.2007.01461.x>

Besag, F.M.C. \& VAsey, M.J. (2019). Social cognition and psychopathology in childhood and adolescence. Epilepsy \& Behavior, 0(0).

Bruner, J. S. (1961). The act of discovery. Harvard Educational Review, 31, 21-32. 
Calderón, M.; Arce, E.; López, M.; Muñoz, B.; Blanco, B.; Madruga, M. et al. (2018). Cryptogenic West syndrome: clinical profile, response to, treatment and prognostic factors. Anales de Pediatría, 89(3), 176-182. $<$ https://doi.org/10.1016/j.anpede.2017.10.006>

Campos-Castelló, J. (2005). Encefalopatías Epilépticas Edad-Dependientes. En Fundación Síndrome de West (2011). Presente y futuro de los síndromes epilépticos pediátricos. Madrid: Fundación Ramón Areces.

Chapple, C. \& Kinsella, W. (2019). Psychoeducational implications of West Syndrome (infantile spasm) for primary school children. Educational Psychology in Practice, 35(3), 271-288.

<https://doi.org/10.1080/02667363.2019.1577222>

Cohen, L.; Manion, L. \& Morrison, K. (2007). Research Methods in Education. New York: Routledge.

De Tiége, X.; Laufs, H.; Boyd, S.; Harkness, W.; Allen, P.; Clark. C.; Connelly \& Cross, J.H. (2007). EEG-fMRI in children with pharmacoresistant focal epilepsy. Epilepsia, 48(2), 385-389. $<$ https://doi.org/10.1111/j.1528-1167.2006.00951.x>

Del Toro, V. (2013). El juego simbólico en alumnos con Síndrome de West y otras Encefalopatías Epilépticas. Revista de Educación Inclusiva, 6(2), 72-87.

- (2016). Imitación en alumnos con Trastornos del espectro Autista: programa de potenciación de habilidades imitativas. Revista nacional e internacional de educación inclusiva, 9(1), 116-133.

Dravet, C. (2011). The core Dravet síndrome phenotype. Epilepsia, 52(2), 3-9. <https://doi.org/10.1111/j.1528-1167.2011.02994.x>

Durá-Travé, T.; Yoldi-Petri, M.E. \& Gallinas-Victoriano, F. (2008). Incidence of epilepsies and epileptic syndromes among children in Navarre, Spain: 2002 though 2005. Journal of Child Neurology, 23(8), 878-882. <https://doi.org/10.1177/0883073808314898>

GaRAigORDOBIL, M. (Noviembre, 2007). Intervención psicoeducativa para el desarrollo de la personalidad infantil. Los programas JUEGO. Congreso internacional de orientación educativa y profesional: "Nuevos enfoques educativos y su repercusión en la orientación escolar". Conferencia Clausura. Universidad Jaume I. Castellón.

Garvey, C. (1990). Play. The developing child. Massachusetts: Harvard University Press.

INGERSOLL, B. \& MeYer, K. (2011). Examination of correlates of different imitative functions in young children with autism spectrum disorders. Research in Autism Spectrum Disorders, 5(3), 1078-1085. $<$ https://doi.org/10.1016/j.rasd.2010.12.001>

INGERSOLL, B. (2010). Brief report: pilot randomized controlled trial on reciprocal imitation training for teaching elicited and spontaneous imitation to children with autism. Journal of Autism and developmental Disorders, 40, 1154-1160. <https://doi.org/10.1007/s10803-010-0966-2>

Kerr, M.; Kluger, G. \& Philip, S. (2011). Evolution and management of LennoxGastaut syndromethrough adolescence and into adulthood: are seizures always the primary issue? Epileptic Disord, 13, 15-26. <https://doi.org/10.1684/epd.2011.0409>

Orock, A.; Logan, S. \& Deak, F. (2018). Munc 18-1 haploinsufficiency impairs learning and memory by reduced synaptic vesicular release in a model of Ohtahara syndrome. Molecular and Cellular Neuroscience, 88, 33-42. <https://doi.org/10.1016/j.mcn.2017.12.002> 
Pavone, P.; Striano, P.; Falsaperla, R.; Pavone, L. \& Ruggieri, M. (2014). Infantile spasms syndrome, West syndrome and related phenotypes: what we know in 2013. Brain and development, 36(9), 739-751. <http://dx.doi.org/10.1016/j.braindev.2013.10.008>

Pikler, E. (1971). Learning of motor skills on the basis of self-induced movements. In J. Hellmuth (ed.). Exceptional Infant: Studies in Abnormalities Vol. 2. New York and London: Bruner / Mazel and Butterworth.

Richards, M.N. 2017). Play. In Reference Module in Neuroscience and Biobehavioral Psychology. Elsevier.

Spenner, B.; Krois-Neudunberger, J.; Kurleman, G.; Althaus, J.; Schwartz, O. \& Fiedler, B. (2019). The Pronostic value of sleep spindles in long-term outcome of West Syndrome. European Journal of Paediatric Neurology. In Press, Corrected Proof, Available online 7 September 2019.

Van Campen, J.S.; Jansen, F.E.; Kleinrensink, N.J.; Jöels, M.; Braun, K.P.J. \& Bruining, H. (2015). Sensory modulation disorders in childhood epilepsy. Journal of Neurodevelopmental Disorders, 7, 34. <https://doi.org/10.1186/s11689-015-9130-9>

VAn RijCkevorsel, R.S. (2006). Cognitive problems related to epilepsy syndromes, especially malignant epilepsies. Seizure, 15(4), 227-234. <https://doi.org/10.1016/j.seizure.2006.02.019>

Wheless, J.W.; Simos, P.G. \& Butler, I.J. (2002). Language dysfunction in epileptic conditions. Seminars in Pediatric Neurology, 9(3), 218-228. $<$ https://doi.org/10.1053/spen.2002.35504>

Williams, J. (2003). Learning and behaviour in children with epilepsy. Epilepsy or Behavior, 4(2), 107-111.

<https://doi.org/10.1016/S1525-5050(03)00024-6> 